\title{
Penggunaan Ampas Batang Pisang Terhadap Pertumbuhan Ikan Mas di Desa Salutambun Barat Kabupaten Mamasa
}

\author{
HASRIA ALANG \\ Jurusan Pendidikan Biologi, Fakultas Matematika dan Ilmu Pengetahuan Alam, STKIP-PI \\ J1. A.P. Pettarani No. 99 B Makassar 90125 \\ email: hasriaalang@yahoo.com
}

\begin{abstract}
The research of the influence of the banana steam residues as pellet for Cyprinus carpio growth has been done at west Salutambun village, Buntu Malangka Districts, Mamasa Counties. The type of this research is experimental study and the aim of this study to see the effect of alternative pellet for Carp (Cyprinus carpio) growth. The research method include the manufacture and testing of alternative pellets for carp (Cyprinus carpio). Alternative pellets consist of banana stem as the main ingredient, a banana peel, fine bran and sweet potato leaves. Everything yielded then mixed with rice water. The pellets are then dried and cured for one night and then milled to from a circle with a small sircle. The data analysis technique used is completely randomized (RAL) is fine that the F value $14,85^{* *}$ is greater than $\mathrm{F}$ table $\alpha 0,01$ with value 13,74 ( $\mathrm{F}$ hitung $>\mathrm{F}$ tabel). Then there is a very significant effect residual use in the manufacture of banana pellets for carp growth at West Salutambun village, Buntu Malangka Districts, Mamasa Counties.
\end{abstract}

Keywords: Cyprinus carpio (carp), growth, pellets

\section{PENDAHULUAN}

Indonesia merupakan negara kepulauan yang memiliki keanekaragaman makhluk hidup yang sangat tinggi. Salah satunya adalah ikan mas (Cyprinus carpio) Ikan mas memiliki kandungan gizi berupa protein, lemak, kalsium, dan zat besi. Semua zat ini bermanfaat bagi kesehatan manusia (Suhardiman, 1997).

Ikan mas memiliki harga jual yang sangat tinggi karena daging ikan mas yang gurih, lembut, padat dan tulang ikan yang dimiliki sangat sedikit. Masa pertumbuhan ikan mas tidak membutuhkan waktu yang lama dan umumnya makanan ikan mas berupa plankton yang ada dalam kolam ataupun pelet yang diberikan oleh petani berupa pakan yang instan atau pun bahan makanan yang sudah jadi. Pakan yang dibutuhkan untuk benih ikan mas selain berupa pakan buatan juga dapat berupa pakan alami (Narantaka, 2012). Pakan buatan ini biasanya dinamakan pelet. Pakan buatan biasanya diproduksi secara besar-besaran di pabrik pengolahan pelet dimana pada pembuatan pellet ini diproduksi oleh para ahli di bidangnya, sedangkan pakan alami yaitu dengan membudidayakan plankton sebagai pakan alami ikan dalam jumlah dan tempat yang banyak atau dengan cara lain adalah dengan menanami benih plankton tertentu agar hanya satu macam atau jenis plankton saja yang dapat tumbuh.

Pelet dapat kita jumpai di toko peternakan, sehingga petani tidak kesulitan untuk mendapatkan bahan makanan ikan tersebut. Menurut Hedianus dan Yohan (petani), para petani di desa Salutambun Barat mengalami kendala dalam pemeliharaan ikan mas karena harga pelet ikan yang cukup mahal.

Tingginya harga pelet tentu akan menambah jumlah biaya operasional petani. Selain itu, penggunaan pakan dalam jangka waktu yang lama akan merusak dan mencemari lingkungan sehingga akan mengganggu keseimbangan ekosistem di dalamnya sehingga perlu diupayakan pemberian pelet yang aman dan relatif lebih murah. Salah satu usaha untuk mengurangi problem pakan adalah berusaha untuk mencari bahan pakan alternatif. Biasanya bahan pakan ini berasal dari tanaman yang ada di daerahdaerah lokal di Indonesia ataupun sesuatu yang kurang umum misalnya limbah ternak/industri/tanaman. Bahan pakan seperti 
ini dikenal dengan nama bahan pangan konvensional, tetapi umumnya belum termanfaatkan secara optimal, kurang dikenal secara akrab sebagai bahan pakan, kurang mempunyai nilai ekonomis dengan harga jual murah dan tersedia dalam jumlah yang relatif banyak.

Hasil penelitian Santoso, et.al (1984) menyatakan bahwa pelet atau pakan alternatif yang menggunakan tepung dari campuran daun pisang dan kulit pisang efektif sebagai pakan unggas karena mempunyai kandungan karbohidrat dan lemak yang relatif tinggi dibandingkan jagung, hanya saja tepung daun pisang mengandung tanin sehingga menyebabkan rasanya menjadi pahit serta penurunan daya cerna asam amino dari unggas tersebut. Lebih lanjut Trisaksono (1994) menambahkan bahwa efek pemberian pakan campuran daun pisang dan kulit pisang akan lebih efektif ketika ditambahkan enzim selulase untuk memudahkan mencerna asam amino.

Penelitian dari Yudianto (1995) juga menyatakan bahwa umbi singkong dan daun nya dapat dijadikan sebagai pakan ternak karena tingginya kandungan protein serta lemaknya. Kandungan ini dapat meningkatkan metabolisme unggas, ditambahkan pula bahwa dedak padi juga mengandung protein yang tinggi.

\section{METODE}

Penelitian ini merupakan jenis penelitian eksperimen yang dilakukan pada bulan MeiJuli 2013 di desa Salutambun Barat, Kecamatan Buntu Malangka kabupaten Mamasa dengan menggunakan 2 petak sawah. Satu petak sebagai kontrol dan satu petak lagi sebagai tempat perlakuan. Pengambilan data melalui observasi dan dokumentasi langsung sedangkan teknik analisis data menggunakan analisis statistik deskriptif RAL.

Bahan yang digunakan untuk membuat pelet adalah batang pisang sebagai bahan utama, kulit pisang, dedak halus, daun ubi jalar, dan singkong. Semua bahan dihaluskan dan diremas dengan air cucian beras lalu dijemur hingga kering. Kemudian diperam selama satu malam untuk selanjutnya digiling hingga membentuk bulatan.

Pemberian pellet/pakan alternatif ini dilakukan selama 2 bulan dan penimbangan berat ikan dilakukan satu kali tiap dua minggu.

\section{HASIL}

Tabel 1. Analisis statistik secara model Rancangan Acak Lengkap (RAL) terhadap pertumbuhan ikan mas yaitu bobot berat ikan mas

\begin{tabular}{lrlrrrr}
\hline \multicolumn{1}{c}{ S.K } & d.b & \multicolumn{1}{c}{ J.K } & K.T & F hitung & \multicolumn{2}{c}{ F tabel } \\
\cline { 3 - 5 } & & & & & 0,05 & 0,01 \\
\hline Perlakuan & 1 & 577812.5 & 577812.5 & $14.85^{* *}$ & 5,99 & 13,74 \\
Galat Percobaan & 6 & 233475 & 38912.5 & & & \\
\hline Total & 7 & 811287.5 & & & & \\
\hline
\end{tabular}

\section{PEMBAHASAN}

Hasil analisis statistik yang diujikan menunjukan bahwa penggunaan ampas batang pisang dalam pembuatan pelet, memiliki perbedaan yang sangat nyata terhadap pertumbuhan ikan mas di desa Salutambun Barat kecamatan Buntu Malangka kabupaten Mamasa, dimana nilai $\mathrm{F}$ hitung $14,85^{* *}$ lebih besar dari nilai $\mathrm{F}$ tabel $\alpha 0,01$ dengan nilai 13,74 (F hitung $>$ F tabel).

Hasil percobaan yang dilakukan dalam penelitian ini menunjukan bahwa penggunaan ampas batang pisang dalam pembuatan pelet terhadap pertumbuhan ikan mas di desa
Salutambun Barat kecamatan Buntu Malangka kabupaten Mamasa memberi pengaruh terhadap berat bobot ikan mas. Hal ini berarti bahwa selain dapat dijadikan pakan unggas seperti penelitian Santoso, et.al (1984) dan Yudianto (1995) bahwa pellet dari ampas batang pisang juga bisa menjadi pakan alternatif untuk pertumbuhan ikan mas. Hal ini dapat terlihat dengan pesatnya pertambahan berat ikan mas yang diberikan pakan alternatif selama dua bulan. Sedangkan ikan yang tidak diberi pakan alternatif, pertumbuhannya sangat lambat. Hal ini memberi sumbangan yang sangat berarti dalam penggunaan ampas 
batang pisang menjadi bahan makanan atau pelet ikan mas secara alami. Dengan ini, petani dapat memanfaatkan ampas pisang menjadi alternatif yang baik dalam perkembangan ikan mas tersebut. Selain itu, pakan alami dapat menurunkan polusi lingkungan dibandingkan pakan instan yang beredar di toko-toko pertanian

Beberapa nutrisi yang dibutuhkan ikan mas dalam pertumbuhannya, yaitu protein yang merupakan nutrien yang dibutuhkan sebagai bahan-bahan pembentuk jaringan tubuh yang baru (pertumbuhan) atau pengganti jaringan tubuh yang rusak, sebagai bahan baku untuk pembentukan enzim, hormon, antibodi dan bahan baku untuk penyusun protein plasma serta sebagai sumber energy. Lemak yang berfungsi sebagai sumber energi dan asam lemak esensial, memelihara bentuk dan fungsi membran atau jaringan sel yang penting bagi organ tubuh tertentu, membantu dalam penyerapan vitamin yang terlarut dalam lemak, bahan baku hormon dan untuk mempertahankan daya apung tubuh. Karbohidrat merupakan sumber energi yang relatif murah dan berguna sebagai prekursor berbagai hasil metabolit intermedier yang sangat diperlukan bagi pertumbuhan, misalnya biosintesis asam-asam amino non-esensial dan asam-asam nukleat (Anonim, 2011). Vitamin dan mineral, dibutuhkan untuk pertumbuhan normal, mempertahankan kondisi tubuh dan reproduksi. Kekurangan vitamin dalam pakan ikan selain akan menyebabkan terganggunya pertumbuhan dan reproduksi juga dapat menimbulkan gejala penyakit kekurangan vitamin sedangkan mineral pada ikan diperlukan untuk menjaga kesehatan tulang, gigi, dan bahkan sisik. Mineral utama yang diperlakukan adalah kalsium dan fosfor.

Batang pisang ternyata kaya akan kandungan mineral seperti kalsium, fosfor karbohidrat (glukosa dan selulosa) namun rendah kadar lignin. Glukosa adalah salah satu karbohidrat terpenting yang digunakan sebagai sumber tenaga bagi hewan. Sementara itu, lignin adalah suatu bentuk serat yang dalam jumlah kecil dibutuhkan ternak untuk membantu pencernaan. Kandungan lignin pada pakan ternak sangat berpengaruh pada kemudahan pakan itu untuk dicerna. Pakan yang rendah kandungan ligninnya mudah dicerna oleh binatang. Bonggol pisang juga mengandung lemak dan protein yang cukup tinggi sehingga dapat menambah pertumbuhan ikan mas.

Dengan adanya penambahan umbi dan daun singkong serta dedak halus, maka kandungan protein dalam pelet alternatif tersebut akan semakin meningkat jumlahnya. Sehingga pertumbuhan ikan mas akan semakin cepat karena protein memegang peranan penting dalam pembentuk jaringan tubuh yang baru (pertumbuhan).

\section{KESIMPULAN}

Dari hasil penelitian, maka dapat disimpulkan bahwa ampas batang pisang dapat dijadikan sebagai pakan (pellet) alternatif dalam pertumbuhan ikan mas di desa Salutanbun Barat kecamatan Buntu Malangka kabupaten Mamasa.

\section{DAFTAR PUSTAKA}

Narantaka AMM. 2012. Pembenihan Ikan Mas. Yogyakarta: PT. Buku Kita.

Suhardiman T. 1997. Budidaya Pisang. Yogyakarta: Penerbit Kanisius.

Santoso U. 1984. Limbah Bahan Ransum Unggas yang Rasional. Jakarta: Bhratara Karya aksara.

Trisaksono A. 1994. Pengaruh Tepung Daun Pisang Dan Penambahan Enzim Dalam Ransum Terhadap Konsumsi Dan Konversi Pakanitik Mojosari Jantan. [Skripsi]. Malang: Fakultas Peternakan UMM.

Widodo W. 2003. Bahan Pangan Non Konvensional. Malang: Fakultas Peternakan UMM.

Yudianto. 1995. Pengaruh Bentuk Dan Ara Ubi Kayu Terhadap Energi Metabolisme Pada Ayam Pedaging Betina. [Skripsi]. Malang: Fakultas Peternakan UMM. 